\title{
Autonomy, Respect, and Arrogance in the Danish Cartoon Controversy
}

Rostbøll, Christian F.

Published in:

Political Theory

DOI:

$10.1177 / 0090591709340138$

Publication date:

2009

Document version

Early version, also known as pre-print

Citation for published version (APA):

Rostbøll, C. F. (2009). Autonomy, Respect, and Arrogance in the Danish Cartoon Controversy. Political Theory, 37(5), 623-648. https://doi.org/10.1177/0090591709340138 


\section{Political Theory}

http://ptx.sagepub.com

\section{Autonomy, Respect, and Arrogance in the Danish Cartoon Controversy \\ Christian F. Rostbøll}

Political Theory 2009; 37; 623 originally published online Jun 16, 2009; DOI: $10.1177 / 0090591709340138$

The online version of this article can be found at: http://ptx.sagepub.com/cgi/content/abstract/37/5/623

\section{Published by:}

(3)SAGE

http://www.sagepublications.com

Additional services and information for Political Theory can be found at:

Email Alerts: http://ptx.sagepub.com/cgi/alerts

Subscriptions: http://ptx.sagepub.com/subscriptions

Reprints: http://www.sagepub.com/journalsReprints.nav

Permissions: http://www.sagepub.com/journalsPermissions.nav

Citations http://ptx.sagepub.com/cgi/content/refs/37/5/623 


\title{
Autonomy, Respect, and Arrogance in the Danish Cartoon Controversy
}

\author{
Christian F. Rostbøll \\ University of Copenhagen, Denmark
}

\begin{abstract}
Autonomy is increasingly rejected as a fundamental principle by liberal political theorists because it is regarded as incompatible with respect for diversity. This article seeks, via an analysis of the Danish cartoon controversy, to show that the relationship between autonomy and diversity is more complex than often posited. Particularly, it asks whether the autonomy defense of freedom of expression encourages disrespect for religious feelings. Autonomy leads to disrespect for diversity only when it is understood as a character ideal that must be promoted as an end in itself. If it by contrast is understood as something we should presume everyone possesses, it provides a strong basis for equal respect among people from diverse cultures. A Kantian conception of autonomy can justify the right to freedom of expression while it at the same time requires that we in the exercise of freedom of expression show respect for others as equals.
\end{abstract}

Keywords: autonomy; diversity; freedom of expression; liberalism; respect

\begin{abstract}
A $\mathrm{s}$ a result of the increased awareness of the importance of cultural diversity among political theorists, the principle of autonomy has now come under attack. Political liberals such as John Rawls and Charles Larmore reject justifying liberal principles on the basis of "comprehensive" conceptions of autonomy; ${ }^{1}$ liberal pluralists such as William Galston hold that liberalism must not take side for autonomy and reflection against tradition and faith; ${ }^{2}$ and libertarian Chandran Kukathas insists that the state has

\footnotetext{
Author's Note: Earlier versions of this article were presented at the Cultural Diversity: Possibilities and Limitations conference organized by the Centre for the Study of Equality and Multiculturalism, Tisvildeleje, Denmark, August 31 and September 1, 2007, and in the Department of Political Science, University of Copenhagen, November 23, 2007. I would like to thank the participants at these occasions as well as Jens Bartelson, Anders Berg-Sørensen, Kasper Møller Hansen, Lene Hansen, Peter Jones, Kathrin Maurer, Noel Parker, Mary Dietz, and two anonymous reviewers for this journal for their comments.
} 
no business in promoting a value such as autonomy, which many people do not regard to be part of their conception of the good. ${ }^{3}$

This article aims, via an analysis of the Danish cartoon controversy, to advance the discussion among political theorists about whether liberalism can rely on autonomy as a fundamental principle. ${ }^{4}$ In order to show that the relationship between autonomy and respect for diversity is more complex than posited in the autonomy/diversity debate, I distinguish two different ways "autonomy" may be understood and consider the relationship between them. In particular, I am interested in how autonomy is used in justifications for freedom of expression and whether these uses are incompatible with respect for diversity. The objection to autonomy-based liberalism that the article responds to in relation to the justification of freedom of expression issue in general and the Danish cartoon case in particular begins from the empirical premise that some minority groups do not place the same value on individual autonomy as some liberal theorists do-and as the Danish majority allegedly does. I argue that if we understand the autonomy that freedom of expression is justified with reference to not as a character ideal that has to be promoted ("Millian autonomy") but as a quality we presuppose everyone has ("Kantian autonomy"), then this principle rather than creating hierarchies among forms of life provides a strong basis for equal respect among people committed to diverse cultures. ${ }^{5}$ Consequently, it would be wrong to blame the "Enlightenment value of autonomy" for the lack of respect for Muslims in the Danish cartoon controversy. Furthermore, it is not only religious minorities who dislike having their fundamental beliefs challenged. Many people feel that it is a violation of their privacy when others attempt to make them change their minds.

My argument relies on a specific (and admittedly debatable) interpretation of the Danish cartoon controversy, specifically of empirical questions of relations of power and status. Thus, the conclusions I draw cannot be evaluated a priori or conceptually but requires also considerations of empirical questions. This, however, is a point of the argument itself: we should not see universal principles as directly applicable to a concrete case without discussion of how best to interpret both principles and the context to which they are applied. ${ }^{6}$ Moreover, the price for political philosophy of not engaging with empirical questions is a political philosophy that "has become a practice whose object is itself . . rather than politics itself."

Thus, I begin with an interpretation of the cartoon controversy, focusing on the broader discourse of which the cartoons were part and on the political and social context in which they were published. I then go on to consider different ways in which autonomy is used to justify freedom of 
expression. The ensuing analysis of the cartoon controversy shows how two different conceptions of autonomy lead, respectively, to arrogance toward and respect for (some) religious feelings. ${ }^{8}$ If freedom of expression is justified as a means to promote autonomy as a character ideal, this easily (if not necessarily) connects with a use of freedom of expression where some are seen as having achieved the ideal while others are seen as having failed. But if freedom of expression is justified with reference to autonomy as a shared human quality, this will demand of us a different kind of humility. While I distinguish "Kantian" and "Millian" conceptions of autonomy and see the first as supplying the constraint against disrespect, we cannot entirely dispense with autonomy as a character ideal. Rather, the promotion of the latter kind of autonomy should be limited by the more fundamental requirement that we treat others as moral equals.

\section{The Cartoon Controversy, Enlightenment Values, and Public Discourse}

When the Danish newspaper Jyllands-Posten in September 2005 published twelve cartoons under the heading "The Face of Muhammad," the aim was "to push back self-imposed limits on expression" and to teach the small Danish Muslim minority that in a secular democracy "one must be prepared to put up with scorn, mockery, and ridicule." The cartoons provoked first a domestic dispute over freedom of expression and the integration of Muslim immigrants in Denmark and later an international crisis with demonstrations and embassy burnings in a number of predominantly Muslim countries. In 2008 the controversy flared up again after the alleged discovery of a plot to murder one of the cartoonists and the republication of his cartoon, the most provocative of the twelve depicting Muhammad with a bomb in the turban.

Of the dividing lines in the Danish public debate about the cartoons, the one drawn between standing firm on Enlightenment values versus giving in to the demand for respect for religious feelings is of particular interest from the perspective of political theory. This way of framing the debate was widespread among those who defended the publication of the cartoons. ${ }^{10}$ On the same day the cartoons were published, the editorial of JyllandsPosten criticized the "political correct" fear of offending Muslims who have a worldview as in the "dark middle ages ... a worldview we in the western world left during the Enlightenment."11 The language of standing firm versus giving in was most prominently used by Danish Prime Minister 
Anders Fogh Rasmussen. One of the actions that led to the escalation of the crisis was his refusal in October 2005 to meet with a group of diplomats from Muslim countries who had complained about the negative portrayal of Islam in the Danish public sphere. ${ }^{12}$ Rasmussen told the press, "This is a matter of principle. I won't meet with them because it is so crystal clear what principles Danish democracy is built upon that there is no reason to do so." ${ }^{13}$ Looking back at the crisis a year later Rasmussen explained, "The Enlightenment ... has been the driving force behind European development and decisive for why we have come as far, as we have. Therefore we have something here [i.e. freedom of expression], with regard to which we cannot give one millimeter." 14 Another top politician wrote during the crisis that it is paramount that "the values of the Enlightenment take hold of more Muslims," which according to her view means that religion "is superseded as the central force that human beings submit to." 15 Jyllands-Posten and its defenders portrayed the conflict as a question of enlightened Danes versus unenlightened Muslims. Specifically, Muslims were seen as insufficiently enlightened because they take their religion too seriously and fail to understand that "satire and caricatures of religious and political authorities are not expressions of disrespect for or ridicule of groups because of their faith or beliefs." 16 The underlying norm was that one ought to keep a critical distance to one's commitments, particularly if these are religious commitments.

The defenders of the cartoons could thus be seen as promoting what has been called Enlightenment liberalism, the core principle of which is autonomy. ${ }^{17}$ They favored near absolute freedom of expression and justified this principle with reference to something akin to the idea that it promotes autonomy. This camp defended the publication of the cartoons on the basis of the conviction that they were a legitimate contribution to vigorous public debate, which is a prerequisite for democracy and progress. The critics of the cartoons in Denmark saw them as an expression of disrespect for the religious feelings of Muslims, indeed as one among many contributions to a pervasive anti-Muslim and anti-immigrant public discourse. A Muslim organization, characteristically, pitted their right to freedom of religion against the right to print the "deeply disrespectful" cartoons. ${ }^{18}$ This contrast seems to fit well into current debates among liberal theorists about the relationship between autonomy and respect for diversity. Galston claims a conflict between the "Enlightenment value" of individual autonomy and the "Reformation value" of respect for diversity. According to his view, Enlightenment liberals are first and foremost committed to the protection and promotion of the ability of individuals to critically reflect on and 
choose their own way of life, while Reformation liberals find it most important to protect diversity, that is, "legitimate differences among individuals and groups over such matters as the nature of the good life, sources of moral authority, reason versus faith, and the like." ${ }^{19}$

The critical conclusions of this article are not so much directed at the cartoons as such but rather at how their publication was justified and defended. This defense must be understood in its discursive context. My discussion, therefore, includes an interpretation of the social, cultural, and political context of the controversy. If the cartoons had been published in an atmosphere that was otherwise characterized by mutual respect and attempts to try to understand and listen to Danish Muslims, there would have been no reason for moral reproach of Jyllands-Posten. But that was clearly not the case. The atmosphere of Danish public debate has for some years, not least since the election in 2001 (and subsequent reelection) of a government that relies on the support of the far-right Danish People's Party, been very hostile toward Muslims, and Jyllands-Posten has been a main contributor to this hostility. ${ }^{20}$ In this context, it is difficult to see the cartoons only as a legitimate critique of religiously justified terrorism and not also and primarily as part of an antagonistic discourse toward Muslims. Moreover, the defense of the cartoons was orchestrated by powerful groups and targeted at a weak minority. ${ }^{21}$ This interpretation of the controversy relies on an assessment of empirical questions and is by no means uncontroversial. However, as mentioned in the introduction, there is no way of applying moral norms to particular cases without engaging in interpretation of the empirical context. Moreover, political theory first becomes truly relevant when it deals with real political issues, which never can be solved by conceptual and normative analysis alone but always involves answering empirical questions in addition.

\section{Autonomy as Justification for Freedom of Expression}

Among liberal political theorists the most common defense of freedom of expression is to invoke the ideal of autonomy. ${ }^{22}$ Millian arguments from truth and arguments from democracy, two other influential justifications for freedom of expression, often are, though they might not have to be, based ultimately on this ideal, too. It is, however, important to note that freedom of expression can be related to and justified on the basis of different conceptions of autonomy. ${ }^{23}$ The core distinction for the argument in this article is 
between justifications that see freedom of expression as a matter of showing respect for everyone's autonomy and justifications that see freedom of expression as promoting personal autonomy.

While I shall end up arguing that the two types of autonomy are mutually interdependent, it is valuable first to consider the different justifications for freedom of expression that they, respectively, can supply and especially the different implications that they, when applied separately, have for how one ought to exercise the right to express oneself freely. When I below describe the two conceptions of autonomy as having different and almost opposed implications, I do this, first, in order to show that they are indeed different conceptions, and, second, in order to argue that Kantian autonomy is the more fundamental one. Even though there are some shortcomings regarding respect for diversity with autonomy as a character ideal, we cannot entirely dispense with this conception of autonomy. Rather, the danger lies in promoting Millian autonomy without concern for the moral constraints on expression required by the Kantian conception of autonomy.

The most influential argument for freedom of expression as constituting respect for individual autonomy is T. M. Scanlon's in "A Theory of Freedom of Expression." "24 According to Scanlon, "The powers of the state are limited to those that citizens could recognize while still regarding themselves as equal, autonomous, rational agents. ${ }^{25}$ To regard oneself as autonomous, "a person must see himself as sovereign in deciding what to believe and in weighing competing reasons for action." This idea of autonomy rules out justifications for restricting freedom of expression that disrespect the individual's ability to determine by herself what to believe and do. Scanlon's conception of autonomy is "Kantian" (if not Kant's own) insofar as autonomy is something that his theory presupposes that everyone possesses. In this view, autonomy is not a product of the exercise of freedom of expression but the a priori reason that it should be protected.

According to the argument that freedom of expression promotes autonomy, autonomy is not presupposed but rather assumed to be fostered by free expression. ${ }^{26}$ This argument relies on the empirical premise that freedom of expression actually does promote an autonomous life. It has its roots in John Stuart Mill who sees freedom of discussion not merely as instrumental to the discovery of truth but perhaps more importantly as a prerequisite for the development of individuality. ${ }^{27}$ If we look at Mill's overall argument for freedom of expression, it includes not only the importance of truth for society as an aggregate but also the personal autonomy that lies in knowing the truth by oneself and acting on it. In this argument, autonomy is a character ideal and not an a priori presupposition. 


\section{Respect for Autonomy and the Exercise of Freedom of Expression}

Is the autonomy defense of freedom of expression a threat to respect for diversity and part of a form of Enlightenment liberalism that is incompatible with religious forms of life $?^{28}$ To answer this question we must analyze which consequences a commitment to autonomy has for the exercise of free expression. My argument assumes that there is a connection between the justification of freedom of expression and how the right ought to be exercised. The concern is how the justification of a right translates into citizens' beliefs about the rights' proper use; in other words, how citizens feel justified and encouraged to act or express themselves in light of the justification of the right. The issue is not the legal limits of freedom of expression but rather how people regulate themselves in their exercise of the right. An unfortunate confusion during the debates over the Muhammad cartoons was that some took any criticism of Jyllands-Posten as expressing a desire to limit the legal right to freedom of expression rather than merely a criticism of its use of the right. But of course we can criticize someone's use of a right without wanting to take it away from her. Not everything we are legally permitted to do is morally right to do; legality does not protect one from moral blame. ${ }^{29}$ The question that the Danish cartoons raise is whether freedom of expression when justified by the principle of autonomy condones or even encourages disrespect for (Muslims') religious feelings in the exercise of freedom of expression.

\section{Promoting Autonomy in the Exercise of Freedom of Expression}

One way of understanding the principle of autonomy entails not only a permission but also an encouragement for people to exercise their right to express themselves freely in a way that disrespects Muslims' religious feelings. If we believe that the reason why we ought to have freedom of expression is that it has the good consequence of promoting critical self-reflection, then we will feel encouraged to use the right to attempt to make others critically reflect on their deepest convictions. If one in addition thinks that Muslims do not hold their beliefs autonomously, then one will feel encouraged to express oneself in ways that one believes will make them critically assess their faith. If the targeted Muslims on their side find the expression disrespectful (and they are not mistaken), ${ }^{30}$ then we have a conflict between autonomy and respect for diversity. 
The way autonomy figures here is as a character ideal that free expression promotes. This view relies on the idea that having an autonomous character is an important good the maximization of which justifies freedom of expression. When freedom of expression is justified with reference to such an idea of excellence, people will regard themselves as warranted in and encouraged to express themselves in ways that help promote the ideal. This relationship between autonomy as a character ideal and encouragement of disrespect for religious feelings is not a necessary one but depends on empirical premises. It is only when one believes others in fact lack autonomy (in this case reflective distance to their faith) that one feels encouraged to disrespectfully provoking them. My point is that autonomy as a character ideal under certain circumstances encourages disrespect for religious feelings because the principle entails no moral constraints that would forbid it. ${ }^{31}$

The conflict between autonomy as a character ideal and respect for Muslims, thus, arises because Muslims are regarded as not having the right relationship to their faith. As quoted earlier, some Danish commentators argued that Muslims failed to understand that caricatures of religious authorities simply are not disrespectful. Muslims were seen as failing to live up to a certain ideal of what it means to be a good citizen. Such a citizen has internalized the Enlightenment value of not being governed by her religion and understands that caricatures of religious figures are not identical to ridicule of those who believe in them. From this point of view, the cartoons could be seen as a justified provocation exactly because they caused offence. The offence taken by some Muslims proved that they lacked the required critical distance to their faith. These Muslims were seen as having failed to achieve the character ideal that freedom of expression is justified with reference to. On this interpretation, the cartoons were meant less to foster autonomy among Muslims than to exhibit their difference.

The danger in justifying freedom of expression on the basis of autonomy as a character ideal is that it may (though it need not) encourage an arrogant use and defense of the right. Some of the comments of JyllandsPosten's editors and those who supported them exhibited a great degree of arrogance and was based on the idea that some Muslims lack a critical distance to their faith - while the editors saw themselves (and the Danish majority) as fully enlightened and as holding a critical distance to their commitments. As argued later, the arrogance in question lies in particular in an imbalance between what one thinks others can learn from oneself and what one thinks one can learn from others. Flemming Rose, the editor who commissioned the cartoons, exhibited this one-sidedness when he explained why he had done so: 
We have a tradition of satire [in Denmark]. . . . The cartoonists treated Islam the same way they treat Christianity, Buddhism, Hinduism and other religions. And by treating Muslims in Denmark as equals they made a point: We are integrating you into the Danish tradition of satire because you are part of our society, not strangers. The cartoons are including, rather than excluding, Muslims. ${ }^{32}$

Rose might want to include Muslims, but it is on his terms; they have to listen to and learn from him, while he has not shown an equal interest in listening to and learning from Muslims. Thus, the arrogance lies not so much in the decision to publish the cartoons as in the rejection of even discussing whether it was a good idea to do so; that is, in the rejection of engaging in dialogue about the limits and use of the right to freedom of expression. My target is not the cartoons as such but rather a particular defense of them, a defense which rejects that we have any obligation to exercise freedom of expression with concern for the religious feelings of others.

So far Galston and other "anti-autonomy" liberals are right: a commitment to Enlightenment values and (a specific use of) autonomy can lead to disrespect for religious minorities..$^{33}$ But that is not the whole story; another use of autonomy works in the opposite direction and supplies a normative foundation for respect for religious feelings.

\section{Respecting Autonomy in the Exercise of Freedom of Expression}

When autonomy is seen as a character ideal that should be promoted and as something some members of society lack, there are no moral constraints on how we speak to each other, as long as the means serves the end. ${ }^{34}$ But there is another way of understanding the principle of autonomy that does impose moral limits on how we speak to each other. This is the Kantian conception according to which autonomy is something everyone is presumed to possess. ${ }^{35}$ When freedom of expression is justified with reference to this principle of autonomy, people are regarded as capable of determining for themselves what to believe and do. If the right to freedom of expression is restricted on the grounds that people are incapable of determining by themselves what is right and wrong, true and false, the state fails to respect people's autonomy so conceived.

My suggestion is that if we as a society are committed to freedom of expression because of the respect it shows for the citizens' autonomy, we 
also ought to show respect for one another's autonomy in our exercise of this right. This respect cannot be legally mandated but is a moral obligation. If the state punished us for not speaking respectfully to each other, $i t$ would disrespect our ability to regulate ourselves. When freedom of expression is justified on the basis of respect for the citizens' autonomy, this entails a very wide legal scope for freedom of expression. ${ }^{36}$ At the same time, it imposes greater obligations on citizens to regulate themselves. If citizens regard themselves as autonomous and in no need of government restrictions on freedom of expression, they must also take upon themselves the obligation to show that they are worthy of this freedom. They do so by living up to the ideal that everyone is treated as autonomous, not merely by the state but also by each other.

According to Kant, to treat someone as autonomous means treating her as a person. A person is something that by its very nature is "an end in itself" and "that may not be used merely as a means." ${ }^{\text {"37 }}$ A person "is exalted above any price" and "possesses a dignity (an absolute inner worth) by which he exacts respect for himself by all other rational beings in the world. ${ }^{" 38}$ The dignity of a person lies in her ability to reflectively choose or endorse her own ends and in doing so in a way that respects everyone's else's equal ability and freedom to do the same. In other words, a person is someone who is able to autonomously choose and revise her own form of life and able to do so under the constraints imposed by a moral law to which everyone is equally subject and author. ${ }^{39}$

There are different uses of respect, and we need to clarify which one connects to the Kantian conception of autonomy. Stephen Darwall argues that we use respect in two different ways, where one, recognition respect, consists in correctly recognizing what the other is and the other, appraisal respect, consists in the positive appraisal of another. ${ }^{40}$ I might recognize that someone is a person, and I show her respect by regulating my conduct based on the recognition of that fact, but it is a very different thing to evaluate someone as a good person and praising her character. "The object of recognition respect is not excellence or merit; it is dignity or authority. Recognition respect concerns, not how something is to be evaluated or appraised, but how our relations to it are to be regulated or governed." ${ }^{41}$ For our discussion, the key difference between these two kinds of respect is that one is independent of anything the object does, while the other must be deserved. In order to be respected as a person one must merely be a person, and the respect consists in that the respecter recognizes that you are a person and acts accordingly. But in order to be positively appraised you have to prove that you merit praise. This also means that recognition respect is 
an either/or (either the other recognizes you as a person or she does not), while appraisal respect can be a matter of degree (when we evaluate others, we rank order them). Finally, "Recognition respect differs . . . in that it can be mandated and not just warranted by its object." ${ }^{" 42}$ I can demand that you respect me as a person but not that you evaluate my achievements positively.

The kind of respect that the Kantian conception of autonomy connects to is recognition respect. Autonomy as a shared human quality is something we respect others as having by recognizing that they are persons. In relation to our discussion of the exercise of a right to freedom of expression, what I find most valuable is the criticism of arrogance involved in the Kantian conception. For Kant, respect for human dignity and autonomy entails a duty "of not exalting oneself above others." 43 We ought to presume that others have reflectively endorsed their ends and that they are good for them and therefore treat them as equals the realization of whose ends is as important as the realization of our own. At the same time, we ought to treat everyone as equally capable of legislating the laws to which everyone is subject. $^{44}$

In Kant, the opposite of arrogance is humility, and it lies in the "consciousness and feeling of the insignificance of one's moral worth in comparison with the moral law." One shows moral arrogance when one is convinced of "the greatness of one's own moral worth, but only from failure to compare it with the moral law," that is, from the failure of according everyone else equal standing as autonomous beings. ${ }^{45}$ As Darwall puts it, arrogance is when one believes that one has a moral standing that other human beings do not have, by believing either that "one has a claim to others' recognition respect but that they reciprocally do not have any against one" or that "one has a fundamental 'lawgiving' standing that others simply don't have." ${ }^{\prime 6}$ One may ask here if the real work isn't done by the traditional moral vocabulary of arrogance and humility rather than autonomy. However, arrogance as used here is defined in terms of the denial of others' autonomy. The Kantian conception of autonomy determines which forms of elevation above others are morally wrong, namely, those where one regards one's own ends as more important than others' ends and denies others an equal lawgiving standing as one's own.

We can now return to the issue of whether grounding freedom of expression in the principle of autonomy encourages disrespect for religious feelings. It might be argued that respecting autonomy entails that speakers as autonomous beings should be able to criticize others' beliefs if they find them wrong and listeners as autonomous beings will be able to make up their minds about what they hear others say. While I do not deny this, and 
also see it as the justification for the legal right to freedom of expression, respect for autonomy in addition requires that we treat others as equals whose (legitimate) ends are as important as our own. Respect for autonomy in the latter sense entails that people should be able equally to live according to their own deepest beliefs and commitments, and hence others cannot be free to disregard these beliefs and commitments in the way they treat them. ${ }^{47}$ Thus, respect for autonomy entails a double requirement in terms of how we ought to exercise our freedom of expression: on one hand, we must presume that speakers and hearers are autonomous and can give and respond to criticism; on the other hand, we must respect each others' ability to endorse and morally constrain our way of life and therefore we cannot disregard others' commitments in the way we speak to them. If people should be able equally to live according to their deepest beliefs, it cannot be right that we should not take these beliefs seriously in the way we treat others.

How does my claim that one ought not to entirely disregard the beliefs of others in the manner one treats them relate to the difference between respecting persons and respecting beliefs? Surely, it might be said, one can criticize someone's belief as seriously wrong and show respect for him or her as a person by treating him or her as capable of receiving criticism and coming to recognize its validity. Particularly, some might find religious faith a serious error and one we owe each other to correct. Moreover, this error might be seen as one even an autonomous person can arrive at, and the certitude by which some people hold it might be one that can be overcome only through something less respectful than the forceless force of the better argument. However, whereas it in some cases is easy to separate criticism and even mockery of beliefs from disrespect for the person, in others it is not. Some of our beliefs are so closely bound up with who we are that we cannot see an attack on them as different from an attack on us. In such cases it is crucial that criticism and mockery be very specifically directed at the content of the beliefs so it can be received as separable from an attack on the person or her group and as distinguishable from a denial of their right to live according to their deepest beliefs. This is what is meant by not entirely disregarding the beliefs of others - not that one cannot criticize others' beliefs or even in some cases mock them. If the justifications behind the cartoons and the discourse of which they were part had been directed at specific errors of belief, rather than at Muslims as such, my evaluation of the case would look different. ${ }^{48}$

To return to the Kantian conception of autonomy, the humility demanded by it shows that it is not a conception of autonomy that encourages disrespect of anyone's beliefs. As Thomas E. Hill argues, modifying Kant, "Basic 
respect calls all the more for modesty and caution to curb our arrogant bias in judging others whom we hardly understand. This requires not only selfdiscipline but also, so far as possible, respectful confrontation and communication with representatives of cultures whose practices we are initially inclined to condemn." ${ }^{\text {"9 }}$ This modesty in judging others' beliefs does not entail relativism or that one cannot engage in critical dialogue with others about their beliefs. Indeed, it is an important aspect of showing respect for others' autonomy that one regards them as capable of responding appropriately to one's criticisms. ${ }^{50}$ Arrogance shows itself in the one-sidedness of believing others can learn from oneself but not the other way around. To treat someone as a person, it is not sufficient that one treats her as reasons responsive - or as capable of understanding cartoons, as some publishers of the Muhammad cartoons thought ${ }^{51}$ —one must in addition respect her as someone both who can contribute with her own ideas and who is equally free to influence the form of public debate. For respect to be reciprocal not only the content but also the form of public deliberation must be based on the principle that everyone should have the right to participate as an equal and also not be discouraged from doing so by their fellow citizens. This is required by the norm of respecting others as having equal standing as colegislators.

To avoid misunderstanding, the point is not that the cartoons by themselves denied Danish Muslims the opportunity to contribute their own perspectives to public deliberation. It was the entire discourse among most defenders of the cartoons that failed to treat Muslims as equal codeliberators. I have mentioned that Prime Minister Rasmussen spoke of freedom of expression as a value that Danes have to stand firm on, indeed a value that cannot be discussed. Other prominent participants in the public debate also insisted that dialogue with Muslims is fine, "as long as one has clarity regarding one's own values and principles, which are nonnegotiable." 52 It was not only the principles in general, not just freedom of expression as such, that were spoken of as nonnegotiable; it was the defenders' own particular interpretation of the principles and their implications that were placed beyond discussion. The principles were treated as something "we" (i.e., Enlightened Westerners) already have sufficient insight into - not only into which principles are important but also exactly what they mean and how to apply them. The arrogance in the defense of the cartoons, then, can be found in that those who did not think vilifying the prophet is a valuable use of freedom of expression were treated as lacking any insight into how to understand freedom of expression. Muslims and sympathetic non-Muslims who complained of disrespect were not treated as disagreeing about the interpretation of universal values, or about the limits or exercise of freedom of 
expression, but as rejecting or not understanding the importance of these values. ${ }^{53}$ They were not treated as autonomous in the sense that they could have equal insight into which moral principles everyone ought to be subject to. ${ }^{54}$

Some might find a moral obligation to respect others' autonomy too vague. It might seem unclear what follows from the failure to adhere to this obligation. Is moral condemnation of Jyllands-Posten all it entails? And is that really sufficient or could it be too much? If disrespect is morally wrong, why shouldn't the state step in and prohibit disrespectful deliberation? Note first that my argument is directed to those who reject that any moral obligations follow from the right to freedom of expression and to those who reject that respecting religious feelings can ever be such an obligation. I argue that if one insists that there be no or few legal restrictions on expression, then one must also accept the obligation to use the right responsibly. This is a response to one of the actual questions raised in the Danish public debate that I believe political theory can contribute to answering. I am defending the proposition that people have a duty to constrain their expression on the basis of the same principle of respect for autonomy that is the ground also of freedom of expression, and from this normative perspective self-regulation is preferable to legal prohibition. Moreover, legally enforced respect will also tend to freeze a certain understanding of respect into law, and this conception of respect will most likely not be a universally shared conception but instead "express the mores of dominant groups." ${ }^{55}$ If we see respect not as a principle with a fully determined content but as something that must be continually reinterpreted and justified by members of all affected cultures in public deliberation, as I think we should, then legal constraints aiming to secure respectful public deliberation can be counterproductive. This does not solve "the problem" that the moral obligation following from the requirement of treating others as autonomous is somewhat vague; it rather opens up for the possibility that this vagueness might be an advantage. The argument against arrogance and dogmatism means that there are no easy solutions in a case like this, and the argument about autonomy implies that the solution is one that citizens must work out together while treating each other as equal deliberative authorities capable of determining and giving the norms everyone is subject to.

\section{The Interdependence of Kantian Autonomy and Autonomy as a Character Ideal}

Until now I have detached Kantian autonomy and Millian autonomy in order to consider their disparate consequences when applied separately. 
However, the sharp contrast between autonomy as something that must be respected in all human beings and autonomy as a character ideal that must be promoted cannot be upheld. To begin with, it might be argued that the Millian conception of autonomy is more plausible than what I have called the Kantian conception because autonomy actually is an achievement that requires us to cast off the tutelage of religious and other dogmas - and that unrestrained public discussion is a prime means to this end. It might furthermore be noted that we find an argument along these lines in "What is Enlightenment?" in which Kant writes that "it would be a crime against human nature" to protect religious authorities and dogmas against criticism because this would hinder the progress toward "maturity" (Mündigkeit). ${ }^{56}$ I have not argued against the permissibility of criticism of religious dogmas but this point nevertheless makes it necessary to stress that the argument is not that we should adopt the Kantian conception of autonomy as opposed to autonomy as a character ideal. Rather, the argument is that respecting autonomy as a shared human quality is the fundamental moral obligation and that it ought to constrain attempts to promote autonomy as a character ideal. The unrestrained promotion of a specific character ideal will set some people's ends and understanding of the good life above others' and thus treat the latter group as mere means.

Could it not be the case, it might also be asked, that the best way to help someone in becoming autonomous actually includes respecting her religious feelings? Thus there would be a consequentialist argument for respectful public expression, and it would be wrong to claim that justifying freedom of expression with reference to the idea that it promotes autonomy fails to place (sufficient) moral constraints on how we speak to each other and encourages disrespect for religious feelings. It is possible that there are good reasons of this sort for criticizing Jyllands-Posten and others who show no concern for the religious feelings of minorities. However, it is not clear that such instrumental reasons will be sufficiently secure to protect minorities against disrespectful expressions. Sometimes respectful discourse is not the best way to make people critically reflect on their commitments. In those cases we would need a more reliable moral constraint. My argument, then, is that even if certain expressions could be shown to promote autonomy they are morally wrong if they do not simultaneously respect the autonomy of the listener. In other words, the autonomy that must be respected is not merely the capacity of the listener for developing an autonomous character (that autonomy is respected in the consequentialist argument) but the presupposed autonomy that lies in the idea that everyone has reasons of their own to contribute with and therefore ought to 
be treated as codeliberators and colegislators. ${ }^{57}$ Moreover, the consequentialist argument relies on the sectarian notion that an autonomous life is better than a nonautonomous life, and thus in its very premise it entails disrespect for members of cultures that do not share that conception of the good.

The main reason that we should not see the two conceptions of autonomy as being in opposition, however, is that it is likely that the promotion of autonomy as a character ideal is a necessary precondition for people showing respect for the autonomy of others. Gerald Gaus has argued that an "ultra-minimal" degree of personal autonomy is required for people being morally autonomous. ${ }^{58}$ People must be capable of self-reflection and role taking in order to understand that other people do not share their conception of the good and in order to respect them equally. Similarly, it could be argued that the humility of which I have spoken requires self-reflection and critical distance to one's deepest commitments. If this is right, my argument could be reformulated as a matter of that the defenders of the cartoons failed to live up to a certain character ideal; their arrogance would then be seen as a failure of self-reflection and role taking.

Where does this leave the argument that justifications for freedom of expression that invoke the ideal of promoting autonomy as a character ideal can encourage disrespect for religious feelings? Is it not the case that promoting autonomy is required for mutual respect rather than being a threat to it? What has been most important for me to argue - mainly as a response to "anti-autonomy liberals" - is that there is an autonomy justification for freedom of expression that rather than encouraging people to disrespect religious feelings actually implies a duty to respect others' morally permissible ends and their equal standing as colegislators. In this conception, autonomy is not a threat to but a ground for respect for diversity. My suggestion is that this conception of autonomy-Kantian autonomy-is the fundamental conception of autonomy because it alone requires us to treat others as moral equals. However, it is true that it is necessary to promote some degree of self-reflection among everyone in a society in order that they may accept and act on the requirements of Kantian autonomy and mutual respect. Thus, we cannot entirely dispense with autonomy as a character ideal that must be promoted. Two points are crucial here: First, this character ideal is not a good in itself but is justified as instrumental to the requirements of equal respect. Critical reflection is not seen as part of a mandated conception of the good life. Second, the content of the ideal is not that everyone must continually submit their conceptions of the good to critical reflection but merely that they are sufficiently self-reflective to 
avoid arrogance and disregard the perspectives of others. In making the case for the value of autonomy, we should not succumb to "the temptation to make it seem not just necessary but admirable." 59

Thus, while the respective goals of respecting and promoting autonomy may indeed clash, they can also at times converge. What should worry us is not promotion of autonomy as such but when it happens without respect for others. And that is exactly the basis of my criticism of the defense of the cartoons in which Danish Muslims were treated perhaps as capable of understanding cartoons but not as holding their convictions autonomously nor as able to give and subject themselves to common principles. One might also interpret the defense of the cartoons as setting up an ideal of free expression and self-reflection in order not to help Muslims becoming more autonomous but to exhibit their inability of becoming so and to show how their presence in Danish society impedes the kind of expression autonomous people have among themselves - and in this way failing to respect them as moral equals.

We should be cautious in assuming that it is only among religious minorities in Western democracies that there is a dislike of autonomy, in particular of the form of critical self-reflection that can be provoked by public discussion and criticism. Empirical studies have shown that there also among the majority in Western democracies is a widespread dislike of having one's fundamental beliefs challenged. A common view is this: "We have a right to our own opinions whatever they are ... and therefore, we ought 'to allow a person to believe what they want to believe.' To try to persuade people to change their minds is an invasion of their privacy and "a violation of their rights." ${ }^{\circ 60}$ This view expresses a conflict between public criticism of fundamental beliefs and individual rights similar to one advocated by some Danish Muslims. So if there is a conflict, it is not one between a secular majority that values autonomy and a religious minority that does not. Rather, it is a conflict that many feel. It is not a conflict between cultures but within cultures. For at the same time that many people do not like to have their fundamental beliefs challenged, they do tend to see themselves as autonomous in the sense that they regard themselves as capable of determining what is good for themselves and also as able to morally constrain themselves. When Danish Muslims claim the right to freedom of religion, they presuppose themselves able to form their own independent judgment in the matter of religion.

It might be asked how much appeal independent judgment in the matter of religion has within Islam. My point is that even if autonomous endorsement of religious beliefs is not important within Islam, Muslims who claim 
the right to freedom of religion must appeal to independent judgment in matters of religion in relation to the surrounding, non-Muslim society. It is difficult to see how they can avoid appealing to some idea of that their beliefs are somehow theirs when they demand that others respect their right to live according to them. This might not require commitment to a strong conception of autonomy, but it does require some idea of that Muslims have positively embraced their beliefs. ${ }^{61}$ In addition,

\begin{abstract}
It makes an essential difference whether a democratic state asks a cultural group to respect "personal autonomy" [what I call Millian autonomy] because of a notion of the good that they might not and need not share, or whether they are asked to respect a form of autonomy to which they themselves need to take recourse when they demand a justification for a political or legal norm and reject ethical "colonization" [i.e., the promotion of one conception of the good at the cost of others]. ${ }^{62}$
\end{abstract}

Thus, the reason why we should see the Kantian conception of autonomy as the most fundamental conception is that it is the conception that Muslims presuppose when they demand to be respected while not sharing the dominant conception of the good life.

\title{
Self-censorship and Its Limits
}

An important question that may be raised at this point is whether my argument restricts expression unduly and leaves too little room for satire and caricatures. After all, this was one of the fears of Jyllands-Posten: that respect for the sensibilities of Danish Muslims would lead to a degree of self-censorship that would harm public debate. First, we should distinguish self-censorship based on concern for the religious feelings of others from fear-induced self-censorship. Certainly, my argument does not condone that anyone is intimidated into silence by threats of violence. Jyllands-Posten justified the cartoons partly by the claim that many Danes were afraid to offend Muslims; however, they failed to point to any concrete examples of threats, and even if they had been able to do so, this would not justify their arrogance toward Muslims. Thus, while the limits of expression should not be set by threats, ${ }^{63}$ this does not mean that there cannot be other reasons for self-restraint in the exercise of freedom of expression.

Second, one cannot judge whether or not the publication of the cartoons showed a morally condemnable disrespect for Danish Muslims without considering the discursive context, which I described earlier. In judging 
whether one's expressions can be regarded as disrespectful and morally wrong, one must consider also the social, cultural, and political position of the addressee. If one addresses a group that is already targeted, powerless, and feels unable to respond, then one must be much more cautious than if one addresses someone whose status as an equal is not in doubt. There is no comparison between ridicule of individuals with political authority or economic power, and ridicule of the weak and marginalized. The normative criterion here is that one ought not to express oneself in ways that undermine the addressee's ability to regard herself as an equal who has equal rights to respect and participation in common affairs. I do not think this criterion would morally condemn all or too many forms of public satire and cartooning. What is special about the Muhammad cartoons is that they are (1) part of a pervasive hateful discourse, (2) orchestrated by powerful groups, and (3) targeted at a marginalized group (4) who already feel discouraged from participating as equals in society.

Doesn't this argument entail that Muslims are treated more favorably than others? Not necessarily. In a country like Denmark, there might be reason to show special concern for Muslims, not because their religious feelings are more important than those of other groups, but because without special care they are likely to be treated worse than others. Because of the homogeneity of Danish culture and the newness of the existence of a Muslim minority, there is a special obligation to attempt to understand the latter and what it means to treat its members with respect. Thus, the problem is not only ill will but also epistemic in the sense that even if one wants to respect others, this is very difficult if one lacks knowledge and understanding of the other's culture and its standards of respect. ${ }^{64}$ In this connection, however, one should recognize the danger of respect turning into patronizing condescension toward Muslims. In practice it is an extremely difficult balance to both recognize the disadvantaged position of someone and to treat him or her as an equal.

Third, the argument that the majority should show special concern toward powerless and often misunderstood minorities should not be regarded as implying that the latter have a veto regarding what counts as wrongful expression. It is not a sufficient reason for concluding that an expression is morally wrong that someone finds it insulting. However, a complaint of this sort should be taken seriously as a reason for restraint that must be considered, if not accepted as it stands. The aim of creating a public culture of mutual respect imposes obligations on both speakers and listeners. Everyone ought to recognize that everyone else, each from his or her perspective, is capable of contributing insights into the shared enterprise of 
determining the proper limits of public discourse. While I have emphasized the violation of this norm by defenders of the cartoons, it is a norm that also listeners - including powerless minorities - can and often do fail to adhere to when they claim to have privileged insight into what respectful deliberation requires.

In light of my use of Kant, it should be emphasized that the preceding arguments are not and cannot be made a priori or in absolute terms. The values of equal power and status are empirical matters and can be justified only in relative terms, that is, in relation to the absolute norm of equal respect for autonomy. It is part of my overall argument that it is legitimate to introduce such empirical questions into debates about what counts as disrespect. Of course, this opens up also for further disagreement, for example, for counterclaims such as that "Muslim power" on a global level is so strong that it inhibits necessary criticism of their beliefs also in Denmark. I find the latter claim farfetched, but of course I cannot close that empirical question here.

If the preceding points are valid, one need not be overly concerned that the type of respectful exercise of freedom of expression that I recommend has too high costs in terms of learning or would require that one abandons the search for truth. Robert Post argues that Jyllands-Posten's cartoons should be allowed, if "public policy is to be directed by intelligently informed public opinion." ${ }^{\prime 65}$ If my analysis is right, it is not the demand for respect for religious feelings that inhibits the formation of an intelligent public opinion in Denmark but rather the arrogance of those who refuse to discuss or listen to the complaints. This does not mean that there cannot be conflicts between the aims of respecting religious feelings and promoting intelligent public opinion. But the cartoon case shows that standing firm on the principle of freedom of expression and rejecting the imperative of showing respect for a marginalized minority is a form arrogance, which if anything inhibits mutual learning.

\section{Conclusion}

The rejection of the principle of autonomy in liberal theory has gone too far. It ignores the different implications with regard to respect for diversity of different conceptions of autonomy. This article has attempted to show this in relation to the justification and exercise of freedom of expression. I have distinguished two conceptions of autonomy and would like in conclusion to outline three models of relating the two conceptions. In the first model, freedom of expression is justified with reference to the idea that it promotes the development of autonomous characters without regarding it is as a central aim to provoke self-reflection among the targeted group in its 
exercise. This might sound paradoxical, but it is nevertheless a possible interpretation of the Danish case: the aim of the cartoons might not have been to promote autonomy among Muslims but to exhibit their difference in terms of a character ideal. The connection to freedom of expression is the belief that Muslims - because of their unreflective religious sensitivityhinder the type of public discourse that autonomous people have among themselves. Here there is no presumption that the targets of "scorn, mockery, and ridicule" are or should be able to develop autonomy.

The second model also posits the promotion of autonomy as a character ideal as the justification for freedom of expression, but its most scornful exercise is now regarded as aiming at provoking self-reflection among those addressed with scorn. With regard to the cartoon controversy, this model implies that Muslims were the addressees and that they were respected as capable of developing autonomy. However, the latter presumption was not regarded as providing a constraint on expression, and there was no commitment to the idea that no one can entirely forfeit respect as an autonomous human being. The discourse defending the cartoons oscillates between these two first models.

In the third model, which is the one I defend, Kantian autonomy is fundamental, and the promotion of a character ideal is seen as having only instrumental value. If I am right about the relationship between the justification and the exercise of a right, this justification should both demand and encourage people to express themselves in ways that show respect for others as autonomous beings. While people know that this is the fundamental moral requirement in the exercise of the right to freedom of expression, they should know also that promoting self-reflection is a prerequisite for mutual respect, and thus in addition feel encouraged to express themselves in ways that lead to this end. Thus, the promotion of autonomy through expression is not wrong but it should be constrained by the more fundamental requirement that we when we engage with others in the public sphere presume that they are autonomous agents who are not only able to respond appropriately to our expressions but who can also contribute with their own, and who must be addressed in ways that do not discourage them from doing so nor disregard their equal ability to live according to their deepest beliefs while respecting others' equal right to do the same.

\section{Notes}

1. John Rawls, Political Liberalism (New York: Columbia University Press, 1993); Charles Larmore, The Autonomy of Morality (New York: Cambridge University Press, 2008), chap. 6 . 
2. William A. Galston, Liberal Pluralism: The Implications of Value Pluralism for Political Theory and Practice (Cambridge, UK: Cambridge University Press, 2002), chap. 2.

3. Chandran Kukathas, "Are There Any Cultural Rights?" in The Rights of Minority Cultures, ed. Will Kymlicka (New York: Oxford University Press, 1995), 228-56, 242.

4. For overviews of the place of autonomy within liberalism, see Will Kymlicka, Contemporary Political Philosophy: An Introduction, 2nd ed. (New York: Oxford University Press, 2002), 229ff.; Kwame Anthony Appiah, The Ethics of Identity (Princeton, NJ: Princeton University Press, 2005), 36ff.; John Christman and Joel Anderson, eds., Autonomy and the Challenges to Liberalism: New Essays (Cambridge, UK: Cambridge University Press, 2005).

5. When I speak of "Kantian" and "Millian" conceptions of autonomy, the understanding of these conceptions is not intended to represent the considered views of either Mill or Kant. The labels are used as a convenient way of referring to ideas that are often associated with Kant and Mill, respectively. However, while the two conceptions of autonomy do not necessarily represent the understandings of autonomy that the two philosophers would subscribe to, they are Kantian and Millian in the sense that they are present in their writings. For these two different uses of "Kantian," see Robert S. Taylor, "Kantian Personal Autonomy," Political Theory 33, no. 5 (October 2005): 602-28, 603.

6 . The article applies a number of moral notions such as autonomy, respect, and arrogance to a concrete case, why it might be called an exercise in applied ethics. It is important to emphasize that such an exercise by no means is a matter of simple deduction giving clearcut answers based on abstract principles applied to an unproblematic case. Cf. Anna Elisabetta Galeotti, "Relativism, Universalism, and Applied Ethics: The Case of Female Circumcision," Constellations 14, no. 1 (2007): 91-111, 105.

7. Avner de-Shalit, Power to the People: Teaching Political Philosophy in Skeptical Times (Lanham, MD: Lexington Books, 2006), 6.

8. It will be noted that I write that "some" and not "all" religious feelings should be respected based on a commitment to Kantian autonomy. In public deliberation, which is my focus, it would give religious groups an improper veto over what counts as wrongful expression if all religious feelings without qualification should be heeded. Rather, the argument is that the principle of autonomy properly understood requires that everyone, speakers and listeners, be respected as capable of contributing insights into determining what constitutes the proper limits of public deliberation. This procedural and democratic approach, of course, relies on substantive moral commitments, and these are the basis for condemning the arrogance of the defenders of the cartoons who - as we shall see - did not respect Muslims' ability to contribute to public deliberation over the limits of freedom of expression. These moral commitments equally imply the wrongfulness of heeding the claims of listeners who demand the right to unilaterally determine the limits of freedom of expression and its proper use.

9. Flemming Rose, "Muhammeds ansigt" [The face of Muhammad], Jyllands-Posten, September 30, 2005, my translation.

10. On the different frames in the Danish news coverage of the controversy, see Peter Hervik and Clarissa Berg, "Denmark: A Political Struggle in Danish Journalism," in Reading the Mohammed Cartoons Controversy: An International Analysis of Press Discourses on Free Speech and Political Spin, ed. Risto Kunelius, et al. (Bochum, Germany: Projekt Verlag, 2007), 25-39.

11. Editorial, "Truslen fra mørket" [The threat from the dark], Jyllands-Posten, September 30, 2005, my translation.

12. On Rasmussen's refusal to meet the ambassadors, see Klaus and Michael Rothstein, Bomben i turbanen [The bomb in the turban] (Copenhagen: Tiderne Skifter, 2006), 32ff. 
13. Quoted from Pernille Ammitzbøll and Vidino Lorenzo, "After the Danish Cartoon Controversy," Middle East Quarterly 14, no. 1 (2007): 3-11.

14. John Hansen, "Jyllands-Posten havde ret til at bringe de tegninger-punktum" [Jyllands-Posten had a right to publish those cartoons - period], interview with Anders Fogh Rasmussen, Jyllands-Posten, October 1, 2006, my translation.

15. Karen Jespersen, "Islam har brug for en oplysningstid" [Islam needs enlightenment], Berlingske Tidende, February 4, 2006, my translation.

16. Karen Jespersen and Ralf Pittelkow, Islamister og naivister-et anklageskrift [Islamists and naivists - an indictment] (Copenhagen: People's Press, 2006), 25, my translation. The authors of this book are, respectively, a former cabinet minister, also cited above, and a commentator at Jyllands-Posten.

17. William A. Galston, “Two Concepts of Liberalism," Ethics 105, no. 3 (April 1995): 516-34.

18. Anders Jerichow and Mille Rode, eds., Profet-affaren: Et PEN-dossier om 12 Muhammed-tegninger — og hvad der siden hoendte [The Prophet Affair: A PEN dossier about 12 Muhammad cartoons - and what followed] (Danish PEN, n.d.), 35ff.

19. Galston, Liberal Pluralism, 21.

20. See Ulf Hedetoft, "Denmark's Cartoon Blowback," openDemocracy, March 1, 2006, http://www.opendemocracy.net/faith-europe_islam/blowback_3315.jsp (accessed March 18, 2008).

21. Jyllands-Posten is Denmark's largest newspaper and is ideologically close to the current government. The newspaper's anti-immigrant and anti-Islam position is widely shared in the Danish population, as indicated both by the widespread support for the government's restrictive immigration policies and in public discourse. See Jørgen Goul Andersen, et al., eds., Det nye politiske landskab: Folketingsvalget 2005 i perspektiv [The new political landscape: Perspectives on the 2005 parliamentary election] (Århus, Denmark: Academia, 2007).

22. Susan J. Brison, "The Autonomy Defense of Free Speech," Ethics 108, no. 2 (January 1998): 312-39, 312ff.

23. I here use the distinction between concept and conception, according to which the concept refers to the overall idea or the core meaning, and conceptions are rival ways of understanding, applying, and/or specifying the concept. See W. B. Gallie, "Essentially Contested Concepts," Proceedings of the Aristotelian Society 56 (1955-56): 167-98; John Rawls, A Theory of Justice, rev. ed. (Cambridge, MA: Belknap, 1999), 5.

24. T. M. Scanlon, "A Theory of Freedom of Expression," in The Difficulty of Tolerance: Essays in Political Philosophy (Cambridge, UK: Cambridge University Press, 2003), 6-25.

25. Ibid., 15.

26. C. Edwin Baker, for example, justifies freedom of expression with reference to its role in fostering self-realization and self-determination. See his Human Liberty and Freedom of Speech (Oxford, UK: Oxford University Press, 1989), 5, 59.

27. See Daniel Jacobson, "Mill on Liberty, Speech, and the Free Society," Philosophy and Public Affairs 29 (2000): 276-309, 294ff.

28. Joshua Cohen has criticized theories that justify freedom of expression on the basis of autonomy for being sectarian. See his "Freedom of Expression," Philosophy and Public Affairs 22, no. 3 (1993): 207-63, $221 \mathrm{ff}$.

29. Joseph H. Carens, "Free Speech and Democratic Norms in the Danish Cartoons Controversy," International Migration 44, no. 5 (2006): 33-42; Christian F. Rostbøll, "Ytringsfrihed, respekt og ansvar" [Freedom of expression, respect, and responsibility], Tidsskriftet Politik 10, no. 4 (2007): 76-85; Ole Wæver, “Aviser og religioner i en globaliseret 
verden" [Newspapers and religions in a globalized world], in Gudebilleder-Ytringsfrihed og religion $i$ en globaliseret verden [Images of God: Freedom of expression and religion in a globalized world], ed. Lisbet Christoffersen (Copenhagen: Tiderne Skifter, 2006), 181-208.

30. Below, I argue that listeners do not have a veto regarding what counts as disrespectful expression.

31. Later, I argue that this constraint can be grounded in the Kantian conception of autonomy, and thus autonomy as a character ideal should not be abandoned but must be constrained by this other conception of autonomy.

32. Flemming Rose, "Why I Published Those Cartoons," Washington Post, February 19, 2006.

33. It may be asked whether Jyllands-Posten and its defenders were committed to any principles at all or paid only lip service to "Enlightenment values" while they were in fact promoting a nationalist project. If that is the case, it is interesting to note how well autonomy as a character ideal serves the latter project. One can also question whether autonomy as a character ideal is an "Enlightenment value." However, my aim is not to enter an argument about how best to understand the Enlightenment but only to engage those who talk about autonomy as an Enlightenment value and who by autonomy seems to refer to something like the character ideal I have been discussing.

34. Below, I consider the objection that "as long as the means serves the end" is a sufficient moral constraint.

35. When I say that all human beings are presumed to possess autonomy, this should be understood as an absolute that implies that no one can altogether forfeit respect as an autonomous human being. I think the same holds for Kant: "Kant typically treats autonomy as an all-or-nothing trait that grounds a basic respect due to all human beings, as opposed to a variable respect earned only by the most conscientious." Thomas E. Hill, Jr., "The Kantian Conception of Autonomy," in Dignity and Practical Reason in Kant's Moral Theory (Ithaca, NY: Cornell University Press, 1992), 76-96, 79; also see Thomas E. Hill, Jr., Respect, Pluralism, and Justice: Kantian Perspectives (New York: Oxford University Press, 2000), 91ff., 108. However, while Kantian autonomy sets an absolute limit on how we can treat others, it is not an absolute in the sense that it implies that one cannot further develop autonomy and approximate some ideal of the rational, independent, and reflective person. Moreover, I do not think we can reduce the Kantian notion to a universal capacity for autonomy since for practical purposes we are required to presume others not merely to be able to develop autonomy but to treat others as always already autonomous beings who can contribute reasons of their own regarding what is right and wrong, valuable and not. It is my hope that my analysis of the cartoon controversy and the discussion below can show the practical importance of this distinction.

36. See David A. J. Richards, Free Speech and the Politics of Identity (Oxford, UK: Oxford University Press, 1999); Rostbøll, "Ytringsfrihed, respekt og ansvar."

37. Immanuel Kant, Groundwork of the Metaphysics of Morals, ed. Mary Gregor (Cambridge, UK: Cambridge University Press, 1997), 37, Ak. 4:428.

38. Immanuel Kant, The Metaphysics of Morals, trans. and ed. Mary Gregor (Cambridge, UK: Cambridge University Press, 1996), 186, Ak. 6:434-35.

39. Also see Hill, Respect, Pluralism, and Justice, 70-72; Rawls, Political Liberalism, 19ff., $81 \mathrm{ff}$.

40. Stephen Darwall, "Two Kinds of Respect," Ethics 88 (1977): 36-49; Darwall, The Second-person Standpoint: Morality, Respect, and Accountability (Cambridge, MA: Harvard University Press, 2006), 122ff. 
41. Darwall, The Second-person Standpoint, 123.

42. Ibid., 120.

43. Kant, Metaphysics of Morals, 199, Ak. 6:449.

44. Kant, Groundwork of the Metaphysics of Morals, 39-42, Ak. 4:431-34.

45. Kant, Metaphysics of Morals, 187, Ak. 6:435.

46. Darwall, The Second-person Standpoint, 136.

47. I am grateful to Peter Jones for this way of putting the point.

48. Some defenders of the cartoons would reply that the cartoons were criticisms of specific beliefs, for example, of the belief in religiously justified terrorism. However, the justification of the cartoons was not primarily that one should be free to mock specific (erroneous and dangerous) beliefs but that one can mock whomever and whatever one wishes no matter the purpose of doing so. It is the latter point I reject. It moves too swiftly from the principle that no beliefs should be held free of criticism to the idea that one can say or publish anything in any context. Cf. Carens, "Free Speech and Democratic Norms in the Danish Cartoons Controversy," 36ff.

49. Hill, Respect, Pluralism, and Justice, 84.

50. See Peter Jones, "Respecting Beliefs and Rebuking Rushdie," British Journal of Political Science 20, no. 4 (October 1990): 415-37, 429.

51. Phillipe Val, the editor of the French satirical magazine Charlie Hebdo, which was brought to court for publishing the cartoons, thus said it was "racist" to claim that all Muslims were hurt by the cartoons because this assumed that they are "not smart enough to understand cartoons." See Jørgen Ullerup, "Muhammed-krig i retslokalet" [Muhammad war in the court room], Jyllands-Posten, February 8, 2007, my translation.

52. Jespersen and Pittelkow, Islamister og naivister, 178, my translation.

53. As Anna Elisabetta Galeotti notes, "Universalists who do not acknowledge the implications of the application of their principles can be both particularistic and dogmatic: particularistic because their views embody particular interpretations, and dogmatic because obscuring such interpretations places them beyond critical scrutiny." See "Relativism, Universalism, and Applied Ethics," 106.

54. I pursue this line of argument further in Christian F. Rostbøll, "The Use and Abuse of 'Universal Values' in the Danish Cartoon Controversy" (paper, American Political Science Association annual meeting, Boston, August 28-31, 2008).

55. Robert Post, "Religion and Freedom of Speech: Portraits of Muhammad," Constellations 14, no. 1 (2007): 72-90, 81.

56. Immanuel Kant, "An Answer to the Question: 'What is Enlightenment?"' in Kant: Political Writings, 2nd ed., ed. Hans Reis (Cambridge, UK: Cambridge University Press, 1991), 54-60, 57. Kant actually does not use the term autonomy in this connection.

57. Also see note 35 above.

58. Gerald F. Gaus, "The Place of Autonomy within Liberalism," in Autonomy and the Challenges to Liberalism: New Essays, ed. John Christman and Joel Anderson (Cambridge, UK: Cambridge University Press, 2005), 272-306, 297-99.

59. Appiah, The Ethics of Identity, 37.

60. Pamela Johnston Conover, Donald D. Searing, and Ivor M. Crewe, "The Deliberative Potential of Political Discussion," British Journal of Political Science 32, no. 1 (2002): 21-62, 55.

61. For strong and weak conceptions of autonomy, see Appiah, The Ethics of Identity, $36 \mathrm{ff}$.

62. Rainer Forst, "A Critical Theory of Multicultural Toleration," in Multiculturalism and Political Theory, ed. Anthony Simon Laden and David Owen (New York: Cambridge University Press, 2007), 292-311, 302ff. 
63. On the point that freedom of expression should not be "placed at the mercy of others' willingness to react in violent and disorderly ways," see Jones, "Respecting Beliefs and Rebuking Rushdie," 435.

64. Also see Christian F. Rostbøll, "Freedom of Expression, Deliberation, Autonomy, and Respect," European Journal of Political Theory (forthcoming).

65. Post, "Religion and Freedom of Speech," 76ff. Post is concerned with legal limits on freedom of expression, but this point is relevant in relation to self-restraint as well.

Christian F. Rostbøll is an assistant professor of political science at the University of Copenhagen, Denmark. His research focuses on deliberative democracy, conceptions of freedom, autonomy, respect, Habermas, and multiculturalism. He is author of Deliberative Freedom: Deliberative Democracy as Critical Theory (2008) and of articles in, among other journals, Political Theory, Philosophy \& Social Criticism, European Journal of Political Theory, and Critical Review of International Social and Political Philosophy. 